\title{
The Conversational Outcomes of Task Implementation
}

\author{
Jeanne Rolin-Ianziti \\ The University of Queensland, Queensland, Australia \\ Email: j.rolinianziti@uq.edu.au
}

Received 18 September 2013; revised 22 October 2013; accepted 30 October 2013

Copyright (C) 2014 by author and Scientific Research Publishing Inc. This work is licensed under the Creative Commons Attribution International License (CC BY). http://creativecommons.org/licenses/by/4.0/ (c) (i) Open Access

\begin{abstract}
Arguing that tasks are primarily a resource to deploy interactions in the classroom, the present study uses a conversation analysis framework to investigate forms of talk resulting from the implementation of the task-based language teaching approach (TBLT) in the second language (L2) classroom. On the basis of three extracts selected from naturally occurring conversations between second semester beginners in French and their teacher as they are completing a comprehension task and a production task in situ, the study uncovers five types of interactions, respectively labeled the teaching interaction, the L1 to L2 how do you say exchange, the correctness interaction, the correction interaction and the repair exchange. Variations across types are apparent in the turn-taking system and in the sequential organization of the interactions. The variations are explained by referring to the characteristics of the two tasks as work plans, as well as to the contextual factors (i.e. the underlying activity and the classroom organization) that are put into place during the implementation of the tasks. Finally, the teaching implications of the study's findings are discussed, arguing that this kind of research may be useful for teacher training purposes insofar as it provides classroom input to reflect upon the processes at play during TBLT implementation.
\end{abstract}

\section{Keywords}

Task-Based Interaction; Task-Based Language Teaching; Conversation Analysis; Classroom Research; Teacher Training

\section{Introduction}

The main role of tasks in second language (L2) teaching is to generate interactions between participants (students and teacher) within the classroom context. Researchers in task-based language teaching (TBLT) commonly define a task as a language learning activity that requires learners to use L2, not by focusing on forms as in 
traditional grammar exercises, but on the expression of meanings (Candlin, 1987; Ellis, 2003; Samuda \& Bygate, 2008). In order to meet this aim, however, a task must fulfill a specific function in L2 teaching. It has to be a language resource that helps create opportunities for learners to communicate in L2. More specifically still, it has to be a teaching tool that fosters interactions between participants within the classroom boundaries (Springer, 2009).

Even though tasks are tools for generating L2 use in the classroom, the interactional features of talk resulting from their implementation have not been the object of many descriptions. There is considerable classroom research on the interactional processes that arise when teacher and students enact lessons (Sinclair \& Coulthard, 1975; Ellis, 1984; van Lier, 1988; Johnson, 1995; van Lier, 1996; Ellis, 2012). Some of this research uses a conversation analysis approach to describe interactions (Kasper, 1985; Seedhouse, 2004) and investigates the relationship between task and classroom language under the rubric of task-based interaction (Mori, 2002; Jenks, 2007; Seedhouse \& Saad Almutairi, 2009). The findings of such studies show the importance of a number of factors in shaping classroom discourse. In particular Seedhouse demonstrates that the pedagogical focus of the lesson influences interactional features. He draws a distinction between four contexts-"form-and-accuracy context; meaning-and-fluency context; task-oriented context; procedural context"-, each producing a different interactional organization (Seedhouse, 2004: p. 138). However, to my knowledge there has not as yet been a systematic examination of the interactions that naturally occur in the classroom when teacher and students perform different types of tasks. There is arguably a need for a thorough investigation of the features of conversations resulting from the implementation of task-based language teaching (TBLT) along the same lines as those devised by Dalton-Puffer to examine the discourse generated in the classroom by the adoption of the Contentbased language teaching approach (Dalton-Puffer, 2007).

An investigation of this kind might prove useful for teacher training purposes. The provision of samples of analyzed interactions resulting from task implementation could be helpful to expose teachers to classroom input during teacher training programs (Markee \& Kasper, 2004; Richards \& Seedhouse, 2005), as well as to have them reflect on ways to implement TBLT. More specifically, samples of interaction could be a springboard for developing in teachers an awareness of the classroom actions that they might have to perform through talk when putting TBLT into practice into the classroom environment.

Hence, in the following study, conducted within a conversation analysis (CA) framework, we attempt to describe the features of forms of talk resulting from the performance of tasks in situ, with the aim of providing some guidance to teachers who wish to introduce TBLT in their professional setting.

\section{The Data}

The study uses audio-recorded naturally occurring conversations of beginners in French who are working in the classroom environment with their teacher on tasks during two lessons, each lesson lasting one hour and twenty minutes. There are approximately 25 students in the class, one-third of whom are males, the other two-third females. All of the students are enrolled in the second semester of an introductory French (L2) course offered in an English (L1) speaking University. Their teacher (T) has about twenty years of classroom experience in the teaching of French at University level as well as at other institutions such as the local Alliance Française. In the recordings of the first lesson, the class accomplishes a reading comprehension task extracted from a teaching unit of the textbook Rond Point 1 (Labascoule, Lause, \& Royer, 2004: p. 72), which claims to adopt a task-based approach to language teaching. In the second lesson the class works on a production task that the teacher has designed prior to teaching time. Whereas in the comprehension task the participants read about how to prepare the French dish, la quiche lorraine, they have to invent a recipe to complete the production task. The production task is reproduced in appendix 1 . The two tasks were selected on the grounds that they are commonly introduced in pedagogical contexts where the class first works on a document then produces a text. Those two moments of a task-based lesson are also constitutive of many units in TBLT textbooks in which students are instructed to read a document before producing a text.

Transcripts of the recordings were established using selectively the CA transcription conventions (see appendix 2). The orthography was not "modified" (Wagner \& Gardner, 2004: p. 6)_to maintain the readability of the transcripts. Readability of the transcripts was deemed essential to meet the aim of the study - that of providing samples of interactions for training practitioners. Future practitioners might not all be familiar with the complexities of CA transcription symbols (Wong \& Waring, 2010: p. 5). Moreover, conventions were added for the 
purpose of transcribing some features of speech, such as language choice (L1 or L2) and L2 errors, which specifically occur in the L2 teaching context. The actions accomplished by participants as they speak, such as reading or writing on the board, were also indicated in the transcripts under the lines transcribing speech. The researcher had observed those actions and taken notes about some non-verbal information during the audio-recording data collection that took place in the classroom.

The first analysis of the transcript reveals that the two tasks as "work plans"- that is in the form of teaching materials prior to classroom use (Candlin, 1987: p. 24; Ellis, 2003: p. 9; Samuda \& Bygate, 2008: p. 10) - generated a number of teaching activities in the classroom setting. The start and end of each activity was clearly identifiable in the transcript, the teacher indicating the end of an activity with words such as $O K$ bon or maintenant (now) and announcing the next activity with statements such as on va or nous allons maintenant (we are going to do next). Then the teacher would give instructions on how to perform the upcoming activity. With the help of such linguistic markers we selected three activities. The first, generated by task 1 , is a reading activity based on the document outlining the quiche recipe. The two other activities are derived from task 2: in the first one the class is creating a recipe in groups of three and in the second one, individual students are reporting to the class the recipe they have just created in groups. As the selected three passages were too long for reporting in this study, we selected one extract from each activity, ending up with three extracts - that is extract 1 in which the class reads the first sentence of the recipe document of task 1, extract 2 where three students create the last sentence of a recipe and extract 3 where individual students of one group out of 6 report to the class the recipe they have just created in groups.

The following examination of the three extracts is conducted within the framework of Conversation Analysis (CA). CA was viewed as the most valuable tool to meet the study purpose because of its connection with professional development. The CA method has an application dimension in particular in the field of education where some researchers have used the approach with the view of improving classroom practice (Richards, 2005). Such a goal seems appropriate to the present study that aims at developing some teacher's awareness on how TBLT might be implemented in the classroom.

Though the analysis is very much data driven, we nevertheless apply two types of organization to the extracts, previously uncovered by CA research, that is the turn-taking system and the sequential organization of talk-ininteraction. To study the turn-taking system or norms governing change of speaker in talk, we use the two main techniques identified by CA for ordinary conversation (Sacks, Schegloff, \& Jefferson, 1974), and applied to classroom interaction by CA applied linguists (McHoul, 1978; Seedhouse, 2004)—that is "self-selection" and "pre-allocation of turns." A current speaker may self-select to speak by initiating talk on her own. Alternatively she may select the next speaker through nomination (designating the speaker by name) or by addressing a question to the next speaker. CA classroom research shows that pre-allocation of turns, performed by the teacher, is prevalent in the L2 classroom and explains this prevalence by the constraints of the educational setting (McHoul, 1978; Drew \& Heritage, 1992; Seedhouse, 2004).

As for the sequential organization of talk, we first identify basic units in the extracts by referring to the fundamental semantic component of conversation-namely the "adjacency pair", or a "sequence" composed of two turns at talk (Sacks, Schegloff, \& Jefferson, 1974: p. 293). Such a sequence is performed by two different speakers, each uttering one turn, and is made up of two closely related turns: the "first pair part" and the "second pair part" in which the speakers complete through talk two logically connected actions (Schegloff, 2007: p. 1). While in the first pair part the speaker initiates talk and projects at the same time a limited number of logically possible responses in the next turn, in the second part the recipient appropriately responds to the action of the first pair. Examples of adjacency pair given by CA for ordinary conversation include pairs of actions such as asking a question and giving an answer or inviting and accepting/rejecting an invitation. As for ordinary conversation, we consider that classroom talk-in-interaction is organized as a succession of adjacency pair or sequences of two turns occurring one after the other. However, each adjacency pair may expand into additional turns or sequences; thus we also apply to our data the types of "expansions" classified by CA according to the location of the expansion in relation to the adjacency pair. In our extracts there are mainly "post-expansions" and "insert expansions". While the first type occurs after an adjacency pair, the second takes place between the first pair part and the second pair part of the adjacency pair (Schegloff, 2007: p. 26). The following example from our data, in which the teacher $(\mathrm{T})$ addresses a student $(\mathrm{S})$ during the reading activity, illustrates a post-expansion:

1 T: qu'est-ce qu'elle ne met pas dans la quiche. what does she not add in the quiche? 
2 S: elle ne met pas de sel she does not add salt

$3 \mathrm{~T}$ : très bien

very good

In this interaction, the teacher $(\mathrm{T})$ checks the students' listening comprehension of an aural document explaining how to prepare a dish. The interaction is composed of one adjacency pair unit. In the first pair part, the teacher (T) asks a question ('qu'est-ce qu'elle ne met pas dans la quiche') and in the second pair part the student (S) coherently responds to the first pair part by answering the teacher's question. The sequence expands, however, into a third turn in which the teacher positively evaluates the student's answer with the expression "très bien". For classroom researchers, this ternary structure dominates in the educational setting where teacher-student exchanges tend to follow a teacher-initiation/student-response/teacher-evaluation pattern (Sinclair \& Coulthard, 1975; Mehan, 1985), referred to as the IRE pattern, though more complex student participatory variations on this pattern have been uncovered by research (Waring, 2009).

Besides post-expansions, we also identify instances of insert expansion in the transcripts such as the following, which is also extracted from our data:

1 S: ajoutez hem $(0.5) \mathrm{xx}$ d'amandes etadd almonds and-

2 T: ajoutez pardon? add pardon me?

3 S: un x d'amandes almonds

ax of almonds

4 T: non avant amandes avant le mot un $\mathrm{x}$

no before almonds before the word ax

5 S: ensuite ensuite

then then

6 T: ensuite ajoutez des amandes, then add almonds

7 S: yeah

8 T: OK très bien oui, OK very good yes

9 S: et du poivre

and pepper

$10 \mathrm{~T}$ : oui

$11 \mathrm{~S}: \quad \begin{aligned} & \text { yes } \\ & \text { et du sel }\end{aligned}$ and salt

In this example, a student accomplishes the third activity, that of reporting to the class the text of a recipe. A repair sequence is embedded within a main turn in which the student is reading a sentence, the reading beginning in line 1 and resuming in line 9. In line 2 the teacher initiates repair (Schegloff, Jefferson \& Sacks, 1977; Kasper, 1985) with the word "pardon" because she does not understand the word preceding "d'amandes" (we were not able to understand it either when establishing the transcript). The insert repair expansion ends in line 8 with the teacher's words "OK très bien" indicating that mutual understanding between the teacher and the student has been re-established after the student's and teacher's completion of the repair in lines 6 and 7 .

We will now proceed to examine the three selected extracts, postponing to a second section of the paper the summary of our findings.

\subsection{Activity 1: Reading a L2 Native Document}

\section{Extract 1}

The class is reading the first sentence of the "quiche" recipe (see Rond Point 1, p. 72)

$\rightarrow \quad$ 1. T: donc nous allons lire la recette (2.0) $\mathrm{OK}$ et on va demander à à $\mathrm{S} 1$ ((nominating $S 1)$ )

2. s'il vous plaît. la la première phrase? (1.0) "tout d'abord":? 
((starting reading $))$

3. hein donc ça ce sont (1.0) les étapes? hein les étapes?

((showing the board where he has written "les étapes" and under "les étapes", "étape 1 étape 2 étape 3"))

4. pour préparer la quiche lorraine?

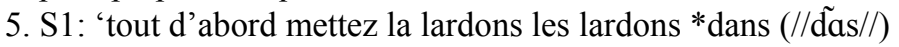

((reading))

6. une (1.0) *poêle $(/ /$ pozl $/ /)$ et (1.0) et les-'

$\rightarrow \quad 7$. T: très bien donc tout d'abord:? donc étape? (1.0) numéro 1 ?

$\downarrow \quad$ 8. (3.0) tout d'abord? hein donc tout d'abord? en anglais?

((writing "tout d'abord" on the board in front of "étape 1"))

9. (4.0) tout d'abord? c'est (2.0) étape numéro 1 tout d'abord?

10. S: firstly

$\uparrow \quad$ 11. T: firstly first of all hein? Donc 'mettez les lardons? vous connaissez ((reading))

$\rightarrow \quad$ 12. les lardons? donc mettez? c'est cette action hein? c'est l'action

((T making gesture))

$\rightarrow \quad$ 13. de mettre to put (1.0)dans une poêle? une poêle? c'est-(1.0)

$\rightarrow \quad$ 14. ça c'est une poêle. voyez l'image? (1.0) ça c'est la poêle.

((T showing picture of the frying pan in task 1 visual document $))$

15. (5.0) la poêle? (2.0)

16. $\mathrm{S}: \mathrm{x}$

17. T: oui c'est ça hein c'est ça la poêle. (3.0) OK (2.0) donc ça c'est ((pointing to the picture again))

18. une poêle en Français. très bien. "et faites-les revenir" donc ((reading))

$\rightarrow \quad$ 19. fai: tes revenir: les lardons: hein revenir ça veut dire? (1.0)

20. cuire hein cook gently. OK * gentiment très bien. merci beaucoup ((T addressing $S 1))$

At the beginning of the extract the teacher gives instructions on how to perform the coming activity saying in French "nous allons lire la recette" (line 1; we are going to read the recipe). The main goal of the activity is then to read a document. Then she asks a student to read aloud the first sentence of the recipe. The student (S1) starts reading the sentence but in line 7 the teacher interrupts her in order to launch into the explanation of the first two words of the text, that is, "tout d'abord" (first of all). Even though the underlying activity of extract 1 is reading, the aim is also to teach the class some vocabulary items extracted from the written document - that is to use written materials "originally intended for L2 native speakers" (Spada \& Fröhlich, 1995: p. 19) to teach the language.

This goal is achieved in the extract through the following sequential organization: the teacher first pre-allocates a turn to a student who is asked to read a sentence from the document; after the student's reading turn, the teacher extracts vocabulary items from the sentence and teaches the selected items to the class in the second adjacent turn. The teacher uses different strategies to explain the vocabulary in the second turn. Besides gesturing (line 12 to teach "mettre"), showing visual information from the textbook (line 14 to teach "la poêle") and using synonym (line 20 to teach "revenir" with the synonym "cuire"), the most frequent strategy is code-switching from L2 to L1. Out of the 13 words extracted from the whole recipe, seven are taught using code switching from L2 to L1.

In extract 1, there are two kinds of code-switching techniques: either the teacher herself initiates and codeswitches from L2 to L1, or she "induces" students to translate words into L1 (Ustünel \& Seedhouse, 2005: p. 315). The first type of organization occurs in line 13 when the teacher rephrases in the same turn the word 'mettre' into to put as well as in line 19 when she switches to cook gently to explain "faire revenir." The second type or teacher-induced code-switching is observable in lines 8 to 11 when the teacher encourages students to code-switch from L2 to L1 to teach "tout d'abord" (first of all). In that case the second turn of the reading interaction expands into another interaction, the aim of which being teaching L2. After extracting "tout d'abord" from the preceding student turn, repeating the words and writing them on the board, the teacher initiates the new sequence by selecting all students as next speakers and translators of the two words: “tout d'abord? en anglais?" 
(in English). Then, after a four-second pause in which no student responds, the teacher re-initiates the interaction: "tout d'abord? c'est" (it's). After the second elicitation, a student (S) appropriately code-switches from the French words "tout d'abord" into the English firstly in a second turn, which the teacher evaluates positively in a third turn, by repeating the code-switch to L1 first of all (line 11). This teaching interaction has then a ternary or IRE structure and occurs as an expansion of the second pair part of the adjacency pair where a nominated student reads a sentence out of a written document in the first pair part.

\subsection{Activity 2: Creating a Text in Group}

\section{Extract 2}

Three students are creating the last sentence of a recipe (see appendix 1$)$.

1. T: maintenant: MasterChef à U? (2.0) nous avons la boîte mystère

2. dans la boîte mystère il y a des ingrédients (1.0) et des produits de base

3. d'accord? on va regarder ensemble les produits de base. donc en

4. équipes vous devez préparer un plat extraordinaire: $\mathrm{OK}$ ? vous êtes les

5. MasterChefs.

((T reads ingredients; the three Ss begin working on recipe; not shown))

$\downarrow \quad$ 6. S1: serve hot. how do you say serve hot.

((creating the last sentence of the recipe))

7. S2: hem

8. S3: hem

$\rightarrow$ 9. S1: hem (2.0) serv- serv- *server (/serve/)?

((hesitating on ending; probably incorrect infinitive ' *server'))

10. S2: I think so +servez (/serve/)

((probably correct imperative ' + servez' $))$

$\rightarrow$ 11. S1: *server [chaud?

((probably incorrect infinitive "*server))

12. S2: chaud]

13. S1: *server (5.0) serve to serve hem

14. S3: *le servi? no that's-

15. S1: $\mathrm{xx}$ oh yeah to serve * server (/serve/) so it would be

$\rightarrow$ 16. *servez $(/$ servez/) + S. E. R. V.E.Z.

((incorrect prononciation)) ((spelling correctly in L1))

17. S2: yeah

18. S1: so *ser: vez? (/servez/) chaud (2.0) et *bon [*appétit (//) on

$\uparrow \quad$ 19. appetit/) ((probably writing))

20. T: OK euh encore] deux minutes? et on écoute? donc euh (1.0) les

21. les dernières étapes s'il vous plaît? n'oubliez pas le nom pour

22. votre plat?

$\rightarrow \quad$ 23. S2: le risotto super

24. S1: le risotto le risotto super. (2.0)

((laughing)) ((probably writing))

25. T: ça va vous av- vous avez tous un nom pour votre plat? (1.0)

26. vous avez tous un nom? (2.0) pour le plat? le plat s'appelle-ça va?

27. (1.0) oui?

$\downarrow \quad 28$. S1: comment dit-on to serve ((addressing $T))$

29. T: pardon?

30. S1: comment dit-on to serve

31. S2: *servez (/serve/)

((probably imperative; incorrect translation of infinitive 'to serve'))

32. T: 'servir' hein? (2.0) donc euh serve + servez

((correct infinitive)) ((correct imperative)) 


\section{S1: + servez $\mathrm{xx}$}

$\rightarrow \quad 34$. T: hein servez S. E. R. V. E. Z c'est le verbe 'servir' ((spelling in L2)) ((writing 'servir' on the board $)$ )

$\uparrow \quad 35 . \mathrm{S} 1:+$ servez chaud.

At the beginning of the extract, the teacher gives the students instructions to the whole class. The students must pretend they are "MasterChefs" and invent "en équipes" (in groups) a recipe using two lists of ingredients. Then the teacher reads the two lists, after which the students proceed to invent a recipe in groups (not shown in the extract). From line 6, three students, S1, S2 and S3 create the last sentence of their recipe as the teacher moves around the classroom to assist groups.

From this point on, the extract is composed of one main sequence or base adjacency pair, which opens with S1's question how do you say serve hot (line 6) and closes with the French equivalent-"servez chaud" (line 35). This sequence is, therefore, organized as one long code switch from the L1 serve hot to the L2 "servez chaud." Within this L1 to L2 switch, three other interactions occur. Whereas the first one, where the teacher interrupts group work for managerial purposes (lines 20 to 27), is unrelated to the main L1 to L2 sequence, the others are closely connected to the action of creating the last sentence of the recipe and thus constitute two insert expansions. While in the first expansion (lines 6 to 19) the three students work on their own, in the second (lines 28 to $34)$ the teacher assists them to find the right form of serve hot in French.

In line 6, S1 initiates the sequence expressing what he wants to say in L1 (serve hot); then he enlists the collaboration of his two peers with the question how do you say serve hot. He then undertakes a self-search for the correct L2 form in the subsequent turns (lines 7 to 19) with minimal participation from his two peers. In the two turns following the question how to you say serve hot, the interjection hem shows that S2 and S3 are uncertain about the answer (lines 7 - 8). Then S1's double self-interruption 'serv- serv-' in line 9 indicates that he is specifically searching for the correct ending to the stem of the verb 'servir' in order to construct the imperative. In the same turn (line 9) he opts for '*server', which S2 positively evaluates in the next turn (line 10) even though the words $I$ think so indicate that he is not sure of the correctness of the form. Furthermore, S2's evaluation is difficult for us to interpret as there is a pronunciation similarity between the ending ER in '*server' and the ending EZ in 'servez', both pronounced (/e/). Consequently, the transcription of S2's turn remains undecided: is it '*server', the incorrect infinitive or '+servez', the correct imperative? S2 may be evaluating one or the other form in his turn. After S2's evaluation, both S1 and S2 make a first switch from the L1 serve hot to the L2 '*server chaud' in lines $11-12$. Again here the similarity in pronunciation between ER and EZ makes it difficult to decide on the right transcription on line 11. Most likely, however, S1 uses the form '*server'. If not he would not resume his search for the correct ending of the verb in line 13. Now he starts with the L1 infinitive to serve, switches to the incorrect L2 infinitive '*server' and ends up with the L2 imperative '* servez', which he pronounces incorrectly and subsequently spells correctly (line 16). In the following turn, S2 positively evaluates the correctness of the form (yeah), which S1 simultaneously writes down and again pronounces incorrectly in the last turn of the insert expansion. At this point of his self-search, which he does with some collaboration from his peers, S1 has got a partially correct answer to the question how do you say serve hot in French. Even though he spells the form 'servez' correctly, he pronounces it incorrectly.

This is the point at which the teacher interrupts group work for management purposes. She initiates an interaction, directed to the whole class, which draws the three students' search away from the French equivalent of serve hot to other matters. In lines 20 and 21 the teacher first deals with time issue telling the students that they have two minutes left to complete the task: 'encore deux minutes' (two minutes left). Then in the same turn she repeats one task instruction - that of naming the dish: 'n'oubliez pas le nom de votre plat' (don't forget the name of your dish). The teacher's intervention has an impact at the group level in the next turn: S2 reacts by naming the recipe 'le super risotto' (line 23).

After the teacher's interruption, S1 re-initiates an interaction with the same question how to say serve hot. However, he now addresses the question in L2 to the teacher and focuses on the infinitive form: 'comment dit-on to serve' (line 28). After the teacher's turn where she initiates repair ('pardon?'), S1 re-initiates the interaction with the question in French in the next turn. In line 34, the teacher finally brings to a close the search for the correct verb ending by providing both the correct L2 infinitive '+servir' for the L1 to serve, and the correct imperative L2 '+servez' after a switch from the L1 imperative serve. After S1's hopefully correct repetition of 'servez,' the teacher spells the imperative and goes to the board to write the verb 'servir.' In a final turn S1 emits the correct answer to the question how do you say serve hot that he raised at the beginning of the extract. He 
now pronounces correctly the L2 expression 'servez chaud' that he was only able to spell correctly in line 18 . The switch from L1 serve hot to L2 'servez chaud' is now completed.

In sum, the main sequence is organized as a search for the correct L2 form of a meaning first expressed in L1. $\mathrm{S} 1$ initiates the search with the question how do you say which he addresses to two different classroom participants and which generates two types of how do you say exchanges. When addressed to his peers, the question enlists participation but produces uncertain or inaccurate L2 answers in subsequent turns; it generates expert answers in the following turns when addressed to the teacher. There is then a transition in extract 2 from the context of peer interaction, where the participants have equal L2 knowledge (even though not all three have the same L2 level, S1 and S2 holding more knowledge than S3), to the context of teacher-learner interaction where $\mathrm{S} 1$ addresses the teacher as an interlocutor having the knowledge to settle the peer discussion on the L2 forms. While both interactions are initiated by the same student, the two how do you say questions generate distinct next turns or answers. In the first exchange students produce hypotheses about how to express L1 meanings in L2; in the second exchange the teacher validates or disproves the hypotheses that were previously raised among peers thus arbitrating on unsettled issues of $\mathrm{L} 2$ forms.

The student-initiated L1 to L2 how do you say exchange exemplified in extract 2 recurs in our data and is typical of the organization of interaction when students are creating texts in a group setting. We calculated the number of occurrences of this how do you say exchange in the twenty three-minute-long group work session during which the three students of extract 2 are creating the "super risotto." The result of the count is 14 interactions involving both code-switching from L1 to L2 and student requests for peer as well as teacher assistance.

\subsection{Activity 3: Reporting to the Class}

\section{Extract 3}

Three individual students are reading out to the class the text of the recipe they have just created in group (see appendix task 2)

1. T: OK on va- vous avez terminé? (2.0) on va écouter? les $(0.5)$

2. les recettes les noms des recettes? OK? donc (1.0) fini (0.5) S1 S2

3. et S3 s'il vous plaît? OK on va commencer par ce groupe? alors

4. comment s'appelle votre plat, comment s'appelle votre plat S1,

((nominating S1 in group 1$)$ )

((Groupl reads recipe; not shown))

$\rightarrow$ 5. T: votre plat, comment s'appelle votre plat,

((addressing student 1 in group 2))

6. S1: il s'appellele risotto super:

((sounding humourous and proud $)$ )

7. Ss: ((laughing))

8. T: le super risotto? (0.5)super risotto oui, $(($ very loud $))(($ class laughing $))$

9. alors s'il vous plait le super risotto la recette,

10. S1: 'tout d'abord coupez un oignon un poivron'

((reading with fluent and assertive voice))

11. T: [hum

$\downarrow \quad$ 12. S1: 'trois] tomates un demi *piment (/pimet/)?'

13. T: un demi +piment (/pimã) oui.

$\uparrow \quad$ 14. S1: '+piment hem 400 grammes de lardons *et (/et/) un poulet entier'

15. T: très bien. (3.0) continuez s'il vous plaît

((addressing student 2 in group 2$)$ )

16. S2: ah ensuite bouil- *bouillez (/bouillez/)

17. T: +bouillez

$\downarrow \quad$ 18. S2: +bouillez *l'eau (/œ/) et ajoutez trois *tasses (/tuset/) de *riz

19. (/ris/)

$\rightarrow$ 20. T: trois: ? (1.0)

21. S?: tasses 
22. $\mathrm{S} 2$ : trois tasses

$\uparrow \quad$ 23. $\mathrm{T}$ : ah trois tasses trois tasses de riz. Très bien continuez

((addressing student 2$)$ )

24. S2: puis bou bouillez du riz

25. T: oui

26. S2: pour $30 *$ minutes (/minyts/)

27. T: très bien. Continuez

((addressing student 3$))$

$\downarrow \quad 28$. S3: ensuite ver hem versez de hem de *l'huile (/ol/) hem d'olive

29. T: oui de + l'huile d'olive versez de l'huile d'olive

30. S3: *à la *poêle (/pocl/)

31. T: dans une +poêle (/pwal/) (0.5) dans une poêle (1.0) in a frying pan

32. S3: oui [oui

33. T: dans (1.0) dans une poêle hein?

$\uparrow \quad 34$. S3: dans une + poêle

35. T: oui

36. S3: et chauffez la poêle $\mathrm{x}$ ?

37. T: chauffez la poêle

38. S3: yeah

39. T: OK

$\downarrow \quad 40 . \mathrm{S} 3$ : puis a[jou

41. T: puis c'est bien]

42. S3: tez oignons et mé- hem mélangez?

43. T: oui

44. S3: pour huit minutes

45. T: oui mélangez pendant huit minutes pour huit minutes oui c'est

$\uparrow \quad$ 46. bien

47. S3: après égouttez le riz

48. T: oui

49. S3: et mettez dans un très grand bol

50. T: oui c'est bien (3.0)

51. S3: $a{ }^{*}$ enfin ( $\tilde{\text { affa }}$ )

52. T: +enfin oui

53. S3: +enfin a- ajoutez: les autres ingrédients (/engridĩat/)

54. T: oui

55. S3: au *riz (/ris/) et: mélangez

56. T: et mélangez très bien, et $(0.5)$ c'est tout,

57. S1: oh servez chaud

58. T: servez chaud

59. S1: oh oh

((laughing; probably because of previous search for the expression in L2; see extract 2$)$ )

60. T: servez chaud très bien servez chaud $(0.5)$ vous recommandez: de

61. manger: le super risotto avec quoi, comme boisson,

62. S2: un vin blanc

63. T: du vin blanc.

$\downarrow \quad 64$. S2: $\mathrm{x}$ bouteille $\mathrm{x}$ Chardonay

65. T: pardon?

66. S2:une bouteille de Chardonay?

$\uparrow \quad$ 67. T: une bouteille de Chardonay. merci beaucoup, votre plat comment

68. s'appelle votre plat s'il vous plaît.

((addressing student 1 in group 3$)$ )

The extract starts with a managerial interaction in which the teacher operates a transition between two activities: the previous activity, creating a recipe, which the students have just completed in groups (see extract 2), 
and the present activity of reporting the created text to the class (this extract 3 ). The question 'vous avez terminé?' (line 1; have you finished?) with a strong raising intonation pattern followed by a pause and the past participle 'fini' (line 2), signal the end of group work. In the same lines the teacher states the goal of the next activity underlining extract 3 using the expression in the future: 'on va écouter les recettes' (we are going to listen to the recipes). Subsequently the teacher designates a first group of students and allocates the turn to one student in the group with the question 'comment s'appelle votre plat, comment s'appelle votre plat' (what's the name of your dish?). After group 1's report (not shown in extract 3), the teacher gives the turn to a student from group 2 through restating the same question (line 5). Extract 3 records the interaction occurring between each of the three students in group 2 and the class during the report activity.

The internal organization of the extract follows a recurrent pattern. First the teacher assigns to a specific student the task of reporting part of the group recipe to the class. After the teacher's pre-allocation of turn, there is an adjacency pair in which the designated student reads out of the recipe in a first turn. The student's turn projects a range of teacher actions in the second turn. If the turn is formally correct, the teacher positively evaluates the student's report. If the turn contains formal errors, the teacher repeats the student's turn 'replacing the errors with what is correct' (Schegloff, Jefferson, \& Sacks, 1977: p. 363). If the student report is unintelligible, the teacher initiates repair, referring to actions taken by speakers to solve problems of understanding (Schegloff, Jefferson, \& Sacks, 1977: p. 363), with a view to re-establishing mutual understanding between him and the class. Three distinctive interactions may therefore occur after the student's first turn: a positive evaluation sequence, a correction sequence, or a repair sequence. We shall now discuss each type in more detail.

The extract comprises many instances where the teacher positively assesses the student's report. The teacher praises the student with words such as 'oui' or 'c'est bien.' She may also use repetition to indicate positive evaluation or correctness. For example in lines 40 to 46 a mix of praise words and correctness repeats occur over three successive adjacency pairs. In the two first pairs, the teacher positively evaluates the student's preceding turns, 'puis' (line 40) and 'mé- hem mélangez?' (line 42), with the words 'c'est bien' (line 41) and 'oui' (line 43). Then in the third pair (lines 44 - 45) she starts the turn with 'oui' and repeats the two preceding correct turns 'mélangez pendant huit minutes pour huit minutes' (mix for eight minutes) followed by the expression 'c'est bien'. Over the three pairs, the teacher positively evaluates the two student turns with the use of correctness repeat as well as with the praise words 'oui' and 'très bien.'

As for correction sequences, they are mostly composed of an adjacency pair followed by a post-expansion. First the student reports a sentence with an error, second the teacher replaces the error with the correct form, and third the student repeats the teacher's correction. For example in line 12, S1 makes a pronunciation error that the teacher corrects in the next turn (line 13); then S1 repeats the teacher correction in a third turn (line 14). However, a correction sequence may expand over more than three turns. For example in lines 28 - 35 the teacher corrects two errors, the pronunciation of 'huile' (oil) and the preposition before 'poêle' (frying pan). As the student does not repeat the correct form after the teacher's turn but instead says 'oui oui' (line 32), the teacher repeats again the correct form '+dans une poêle', which triggers the student's repetition of the correct form in the next turn (line 34).

Two instances of repair sequences occur in the extract. In line 20, the teacher initiates repair repeating the word 'trois?' (three) followed by raising intonation because she does not understand the following word 'tasse' (cup) that the student has incorrectly pronounced in the previous turn. After a one-second pause, another student in group 2 completes the repair saying 'tasses' correctly, and then S2 repeats the repair completion, 'trois tasses', which the teacher then repeats in line 23 after the interjection 'ah' indicating that mutual understanding has been re-established ('ah trois tasses trois tasses de riz'). Similarly, in line 65, the teacher initiates repair because she has not understood S2's attempt at saying 'une bouteille de Chardonnay' (a bottle of Chardonnay); S2 completes repair in the following turn and, in a final turn, the teacher repeats S2's repair completion, thus communicating to the class that understanding has been re-established.

Many actions in the activity of reporting take the shape of a repeat of the preceding turn either with or without modifications. While the teacher signals positive evaluation through a repeat of the student's preceding turn, the action of correcting may involve two repeats: the teacher's repeat of the student's turn but with no error, and the student's repeat of the teacher's corrected utterance. In repair sequences, the teacher's repeat of the student's repair communicates to the class that the understanding problem has been reached. The use of repeat fulfils various functions among which we can identify indicating correctness or positive evaluation, practicing correct utterances, and signalling the re-establishment of mutual understanding in repair sequence. 


\section{Summary of Findings}

The three above analysed extracts display five major types of interactions, each having its own sequential organization. As shown in Table 1, each type has been labelled by specifying the main action that the participants achieve through talk-in-interaction. Main actions include teaching, asking for L2 information, positively evaluating, correcting and, finally initiating and completing repair. The first type, the teaching interaction, appears in extract 1, the second type, asking for L2 information or the 'L1 to L2 how do you say exchange' arises in extract 2 ; and the last three, the positive evaluation interaction, the correction interaction and the repair interaction occur in extract 3. Table 1 outlines the five types in the left column and the passages of the extracts where each type appears in the right column.

Table 2 summarizes the sequential organization for each interaction with a view to showing conversational differences across types. The top row indicates the sequence of turns (the turn allocation, then the first pair part and the second pair part of the adjacency pair) as well as insert and post-expansions, when such expansions occur in the organization of a type. The second row specifies the action performed in each turn, and the third row outlines which participant (teacher or student) enacts each action recorded in the second row. Lastly in the fourth row, an example extracted from our data illustrates each type.

As shown in Table 1, interactional types do not occur across all three extracts. Whereas the ternary teaching interaction,' only appears in extract 1, 'the L1 to L2 how do you say exchange' is solely observable in extract 2 and the three last types, ('the positive evaluation interaction,' 'the correction interaction' and 'the repair interaction') are only identifiable in extract 3. The characteristics of the tasks as work plans, as well as the types of activities that the tasks generate in the classroom environment, account for this fact. In our data the participants first work on a comprehension task (task 1), then on a production task (task 2) these two tasks deploying different classroom activities in situ. While the activities resulting from the performance of task 1 are reading and teaching vocabulary, those arising from the completion of task 2 are respectively text creating and reporting to the class. Furthermore, in order to be carried out in the context of the classroom, each activity requires a specific organization of the participants. While the teaching activity takes place within a teacher-fronted setting, the text creation is performed in groups (with the teacher moving around the class to monitor the activity) and in the reporting activity individual students read to the whole class the text they have previously created in groups. The activities (together with the participants' organizations) resulting from the implementation of the tasks (each having distinct characteristics) create specific contexts in the classroom and these in turn impact on the organization of the interactions. Table 3 outlines in the left column each of the five interactional types; it then lists in column 2 the task as work plan, and in columns 3 and 4 the two contextual factors (the generated activity and classroom organization) that influence the sequential organization of each type.

Such contextual variations as task, activity and classroom organization, delineate different exchanges in the classroom, each having its own structure of turn allocation and its own sequential organization. The pre-allocation of turns, which previous research has shown to be prevalent in the formal setting of the classroom (McHoul, 1978), occurs in our data, but only in the context of the teacher-fronted teaching activity and in that of individual students' reporting to the class. In contrast, student self-selection either to initiate speech with peers or with the teacher is solely identifiable during the text creation activity completed in groups. As for sequential organization, the ternary structure or IRE is only observable in the context of the teacher instructing the class about vocabulary, and disappears in other contexts, in particular during the creation of L2 texts in groups where another sequential organization emerges. This latter is one in which not the teacher but the student initiates talk for obtaining L2 information from the teacher, and in which the teacher responds not as an evaluator of student L2

Table 1. Interactional types uncovered in the three extracts.

\begin{tabular}{|c|c|}
\hline Type & Reference to lines in extract \\
\hline 1. Ternary teaching interaction & Extract 1 , lines 7 to 11 \\
\hline 2. Asking for L2 information or L1 to L2 how do you say exchange & Extract 2 , lines 6 to 19 and 28 to 35 \\
\hline 3. Positive evaluation interaction & Extract 3 , lines 40 to 46 \\
\hline 4. Correction interaction & Extract 3 , lines 28 to 35 \\
\hline 5. Repair interaction & Extract 3 , lines 18 to 23 and 64 to 67 \\
\hline
\end{tabular}


Table 2. Sequential organization for each type. (a) Ternary teaching interaction (occurring as expansion of reading interaction); (b) L1 to L2 how do you say exchange; (c) Positive evaluation interaction; (d) Correction interaction; (e) Repair interaction.

(a)

\begin{tabular}{cccccc}
\hline Turn & Turn allocation & Reading turn 1 & $\begin{array}{c}\text { Reading turn 2 and } \\
\text { teaching turn 1 }\end{array}$ & Teaching turn 2 & Teaching turn 3 \\
Action & Pre-allocating turn & Reading & $\begin{array}{c}\text { Selecting word (s) } \\
\text { for teaching in reading } \\
\text { turn 1 and initiating } \\
\text { L1 switch }\end{array}$ & Switching to L1 & $\begin{array}{c}\text { Evaluating } \\
\text { L1 switch }\end{array}$ \\
Participant & Teacher & Student & Teacher & Student & Teacher \\
Example & $\begin{array}{c}\text { On va demander à } \\
\text { S1 s'il vous plaît.la } \\
\text { première phrase }\end{array}$ & $\begin{array}{c}\text { Tout d'abord mettez } \\
\text { les lardons dans une } \\
\text { poêle dans une poêle }\end{array}$ & $\begin{array}{c}\text { Tout d'abord? } \\
\text { en anglais? }\end{array}$ & Firstly & Firstly first of all \\
\hline
\end{tabular}

(b)

\begin{tabular}{|c|c|c|c|c|c|c|c|}
\hline Turn & $\begin{array}{c}\text { First } \\
\text { pair part }\end{array}$ & $\begin{array}{l}\text { First insert } \\
\text { expansion } \\
\text { turn } 1\end{array}$ & $\begin{array}{l}\text { First insert } \\
\text { expansion } \\
\text { turn } 2\end{array}$ & $\begin{array}{l}\text { First insert } \\
\text { expansion } \\
\text { turn } 3\end{array}$ & $\begin{array}{l}\text { Second insert } \\
\text { expansion } \\
\text { turn } 1\end{array}$ & $\begin{array}{l}\text { Second insert } \\
\text { expansion } \\
\text { turn } 2\end{array}$ & $\begin{array}{l}\text { Second } \\
\text { pair part }\end{array}$ \\
\hline Action & $\begin{array}{l}\text { Self-selecting to } \\
\text { speak/expressing } \\
\text { meaning in L1 }\end{array}$ & $\begin{array}{l}\text { Asking question } \\
\text { on how to say L1 } \\
\text { meaning in L2 }\end{array}$ & $\begin{array}{l}\text { Searching L2 } \\
\text { answer }\end{array}$ & $\begin{array}{l}\text { Finding partial L2 } \\
\text { answer (correct } \\
\text { spelling, incorrect } \\
\text { pronunciation) }\end{array}$ & $\begin{array}{l}\text { Self-selecting } \\
\text { to speak/asking } \\
\text { how to say L1 } \\
\text { word in L2 }\end{array}$ & $\begin{array}{l}\text { Providing L2 } \\
\text { expert answer }\end{array}$ & $\begin{array}{c}\text { Repeating } \\
\text { L2 } \\
\text { answer/answering } \\
\text { self-raised } \\
\text { L1 question }\end{array}$ \\
\hline Participant & $\begin{array}{c}\text { Group leader } \\
\text { student }\end{array}$ & $\begin{array}{l}\text { Group leader } \\
\text { student }\end{array}$ & Peers & $\begin{array}{l}\text { Group leader } \\
\text { student }\end{array}$ & $\begin{array}{c}\text { Group leader } \\
\text { student }\end{array}$ & Teacher & $\begin{array}{l}\text { Group leader } \\
\text { student }\end{array}$ \\
\hline $\begin{array}{c}\text { Example } \\
(\text { extract } 2 \text {, } \\
\text { lines } 6-16 \\
\text { and } 28-35)\end{array}$ & Serve hot & $\begin{array}{c}\text { How do you say } \\
\text { serve hot }\end{array}$ & Hem hem & S.E.R.V.E.Z & $\begin{array}{l}\text { Comment } \\
\text { dit-on to } \\
\text { serve }\end{array}$ & $\begin{array}{c}\text { 'Servir' hein? } \\
\text { donc euh } \\
\text { serve + servez }\end{array}$ & Servez chaud \\
\hline
\end{tabular}

(c)

\begin{tabular}{cccc}
\hline Turn & Turn allocation & First pair part & Second pair part \\
Action & Pre-allocating turn & Reading from own text & Evaluating positively \\
Participant & Teacher & Student & Oui mélangez pour huit minutes \\
Example & Continuez & Mélangez pour huit minutes & pendant huit minutes c'est bien \\
\hline
\end{tabular}

(d)

\begin{tabular}{|c|c|c|c|c|}
\hline Turn & Turn allocation & First pair part & Second pair part & $\begin{array}{l}\text { Post expansion } \\
\text { third turn }\end{array}$ \\
\hline Action & Pre-allocating turn & $\begin{array}{l}\text { Reading intelligible } \\
\text { sentence from own } \\
\text { text with error(s) }\end{array}$ & $\begin{array}{l}\text { Repeating replacing } \\
\text { error(s) with what } \\
\text { is correct }\end{array}$ & $\begin{array}{c}\text { Repeating corrected } \\
\text { utterance }\end{array}$ \\
\hline Participant & Teacher & Student & Teacher & Student \\
\hline $\begin{array}{c}\text { Example } \\
(\text { extract } 3 \text {, lines } 15-18)\end{array}$ & Continuez s'il vous plaît & Ensuite ${ }^{*}$ bouillez l'eau & + Bouillez & +Bouillez *l'eau \\
\hline
\end{tabular}

(e)

\begin{tabular}{|c|c|c|c|c|c|}
\hline Turn & Turn allocation & First pair part & Insert expansion turn & Insert expansion turn & Second pair part \\
\hline Action & Pre-allocating turn & $\begin{array}{l}\text { Reading unintelligible } \\
\text { sentence from own text }\end{array}$ & Initiating repair & Completing repair & $\begin{array}{l}\text { Repeating repair } \\
\text { completion }\end{array}$ \\
\hline Participant & Teacher & Student & Teacher & Student & Teacher \\
\hline $\begin{array}{c}\text { Example } \\
\text { (extract } 3 \text {, lines } \\
15,18-23)\end{array}$ & $\begin{array}{l}\text { Continuez s'il } \\
\text { vous plaît }\end{array}$ & $\begin{array}{l}\text { Ajoutez trois } \\
{ }^{*} \text { tasses de riz }\end{array}$ & Trois? & Tasses & $\begin{array}{c}\text { Ah ajoutez trois } \\
\text { tasses de riz }\end{array}$ \\
\hline
\end{tabular}


Table 3. Influence of task as workplan and classroom contextual factors on interactional types.

\begin{tabular}{llll}
\hline Interactional type & Task as workplan & Generated classroom activity & Generated classroom organization \\
\hline $\begin{array}{l}\text { 1. } \\
\text { Ternary teaching interaction }\end{array}$ & Task 1: Comprehension & Reading and explaining vocabulary & $\mathrm{T} \rightarrow$ class \\
$\begin{array}{l}\text { 2. } \\
\text { L1 to L2 asking for information } \\
\text { sequence or L1 to L2 how } \\
\text { do you say exchange }\end{array}$ & Task 2: Production & Creating a L2 text & SSS SSS SSS \\
$\begin{array}{l}\text { 3. } \\
\text { Positive evaluation interaction }\end{array}$ & Task 2: Production & Reporting task outcome & AND \\
$\begin{array}{l}\text { 4. } \\
\text { Correction interaction }\end{array}$ & Task 2: Production & Reporting task outcome & $\mathrm{S} \rightarrow$ class \\
$\begin{array}{l}\text { 5. } \\
\text { Repair interaction }\end{array}$ & Task 2: Production & Reporting task outcome & $\mathrm{S} \rightarrow$ class \\
\hline
\end{tabular}

performance but as an expert in L2 knowledge. Furthermore, the repair organization appears only in the context of reporting where the teacher initiates talk, not to instruct students, but because she has not understood the student's report and she aims at re-establishing mutual understanding between herself and the class.

The examination of our data shows that TBLT introduces a range of interactions in the classroom. The variety is due to the task characteristics, fostering either comprehension or production, but also to the activities and the participants' organizations, which the teacher derives from the tasks as work plans and implements in the classroom. The activities resulting from the work plans create distinct contexts within the classroom, each context affecting differently the organization of talk. The analysis of our data disproves previous research, which has argued for the dominance of one form of talk in the classroom-the ternary structure (Sinclair \& Coulthard, 1975). Our analysis on the contrary confirms the results of studies that emphasize the diversity of classroom talk (Markee \& Kasper, 2004), particularly studies that relate interactional variations to changes in pedagogical context (Seedhouse, 2004). In our data, however, the diversity results from the introduction of TBLT in the classroom. TBLT, in offering a range of tasks, opens up the possibility of deploying various activities in the classroom, each activity requiring participants to perform specific forms of talk.

\section{Teaching Implications}

Some, but not necessarily all of the interactions uncovered in this study may already be familiar to teachers. It is hoped that the above three extracts can be used as exemplars for teachers to reflect on what they may expect to have to enact through talk when implementing TBLT in the classroom. More generally the findings of this study may help educational practitioners to plan the future introduction of TBLT in their professional environment. The following remarks will focus on four main actions: interpreting tasks, teaching vocabulary from written documents, supporting group work and correcting, all of which may be viewed as particularly important for the deployment of TBLT materials in the classroom.

Each extract starts out with the teacher giving instructions to the class on how to perform the upcoming activity. Those instructions give some indication as to the teacher's interpretation of the tasks as work plans - that is about how she has converted task 1 and task 2 as teaching materials into activities to be carried out in the classroom. Such conversion involves making decisions on which activities to perform in class but also on the appropriate classroom organization to adopt in order to accomplish the activities. In our data, whereas the teacher translates task 1 into a reading and teaching activity performed in a teacher fronted setting, she converts task 2 into a teacher supported group work activity, during which students create a text that they report to the whole class in a post-task phase. The instructions opening the above extracts may therefore be a springboard for training teachers to adapt tasks for the classroom and write lesson plans. The training could take the shape of a discussion of other possible adaptations for tasks 1 and 2 than those devised in our data, taking into account the various characteristics of teaching contexts, such as students' level, time constraints or course objectives. Other adaptations could include for example planning a reading activity for task 1, but performed in groups instead of teacher-fronted, or writing a recipe book as a possible outcome for task 2 instead of reporting to the class.

As for the interactional content of extract 1, it could offer practitioners an exemplar as to how to teach vo- 
cabulary from written documents, such documents being an essential component of TBLT teaching materials. From such an exemplar teacher trainees could evaluate the teacher's strategies, as for example that involving the use of IRE interaction to teach 'tout d'abord.' They might reflect on the value of such IRE strategy as a means of having students access the meaning of words and, more generally, to teach L2 language interactively. Other words selected out of the document but not taught by the teacher in our data, or selected from other written materials, might be used to have teachers practice or discuss strategies on how to introduce vocabulary in the context of a reading activity.

Two main aspects of group work are observable in extract 2 and, we believe, emerge in our data because of the introduction of the TBLT method in the classroom environment. The first, which is apparent in the sequential organization of talk in extract 2, regards the strategies students enact to create a meaningful text, while the second concerns the teacher's role in a group work setting in which students frequently initiate how do you say exchanges to request assistance from the teacher. As the analysis of the organization of student talk has uncovered in extract 2, students tend first to word in L1 the meaning they wish to express in L2; then they subsequently collaborate through talking in order to find the correct L2 forms to word the L1 meaning, the exchange ending after several turns with a switch to L2. Introducing future teachers to the organization of extract 2 could lead to a discussion on whether it is appropriate or not to encourage such a strategy among students, with possible references to previous positions taken by immersion approaches against the use of L1, as well as to more recent and extensive research on L1 use in the classroom, which has somewhat eased the century-old ban on L1 (Macaro, 2001; Turnbull \& Dailey-O'Cain, 2009). As for the teacher's role during group work, it is hoped that the opportunity to observe instances of the how do you say exchange in extract 2 could help future teachers anticipate the kind of support they will have to give students during task completion in groups. In such a setting, the students frequently ask teachers for translations of L1 words into L2 or, as in extract 2, for arbitration on hypotheses about L2 forms that they have previously discussed among themselves. In this interactive context, the teacher must improvise a response to the preceding turn in which a student has initiated talk to ask a question the content of which she can hardly, or not at all, predict.

Finally, extract 3 provides input for a discussion on how to evaluate interactively students' work in the task-based classroom. Besides, the use of correctness repeat which is available to teachers as a means of positively assessing student previous turns, the extract shows two distinct ways to deal with students' erroneous turns during the report of task outcome to the class. First the teacher may have to correct formal errors coming from turns that are intelligible to her; second she might have to initiate repair when she does not understand the student's preceding turn. In the first case, the teacher reacts to the student's utterance by replacing errors by what is correct and afterwards she may require from the student a repeat of her reworded turn if the student does not spontaneously repeat the teacher's correct turn. In the second case, the teacher must initiate repair before correcting because of the unintelligibility of the student's turn. In this second case, the teacher is in a situation similar to that of every conversation where the construction of meaning occurs moment-by-moment in response to the previous turn and where participants frequently repair talk to ensure understanding between them.

In sum, whereas extract 1 is helpful to show how to teach L2 interactively from written documents, the two other extracts may assist teachers in anticipating the interactive requirements which are needed to teach language with TBLT in the classroom. In the first extract, the interaction has an IRE pattern, the function of which is to test students' knowledge on a teacher preselected lexical item. In the two other extracts, the students initiate speech in order to express meanings the teacher cannot predict beforehand. In the how do you say exchange, the student self-selects to take the floor in an interaction whose aim is to obtain language assistance from the teacher, the latter being required to improvise an answer appropriate to the request. Similarly, though the teacher gives the floor to individual students in the report activity, the students in the following turns read out of a text whose content, being the outcome of the task, is unpredictable to the teacher as it is the students' own creation. The teacher must then correct students' productions as the need arises. While the teacher has a chance to select the language she wants to test when initiating an IRE interaction, the teacher has to improvise responses to the unpredictable questions or productions initiated by students in both of the other exchanges.

The requirement to make appropriate responses-that is to construct exchanges moment-by-moment in real time during the teaching lesson, is a constitutive feature of language teaching communication (Cicurel, 2011). Not only TBLT, but also the implementation of other language teaching methods demands that teachers improvise talk in the classroom. However TBLT, which favours group work and student participation, requires, when implemented, a more frequent need from the teacher to respond to student-initiated talk without preparation. 
Even though most teachers may have acquired the ability to participate in student-initiated exchanges through experience, novice teachers may find that they lack the expertise required to contribute appropriately to such interactions and, more generally, that such participation is quite challenging and possibly even face threatening.

\section{Conclusion}

This study, an analysis of the classroom language arising from TBLT implementation, has uncovered five different types of talk in naturally occurring data collected when students and their teacher are completing a comprehension task and production task. It has argued that variations in turn-taking and in sequential organization are due to task characteristics as well as to the activities derived by the teacher from the tasks as work plans. The teaching implications of the findings have been stressed with a view to providing some guidance to professionals who might be considering introducing TBLT in their institutional environment. Though reasons can be given to support using extracts from classroom data to promote professional development, the present study suggests that there is a need for further research in education to help teachers deal with the specific interactive requirements of the task-based classroom. Whereas it seems quite unproblematic to train teachers to use the talk required to teach L2 with written documents, more research should be directed towards exploring ways to develop in teachers the expertise of improvising the talk which TBLT implementation necessitates in order to respond to student questions and to correct task-outcomes.

\section{References}

Candlin, C. N. (1987). Towards Task-Based Language Learning. In C. Candlin, \& D. Murphy (Eds.), Language Learning Tasks (pp. 5-22). Lancaster Practical Papers in English. Lancaster: Lancaster University.

Cicurel, F. (2011). Les Interactions Dans l'Enseignement des Langues. Agir Professoral et Pratiques de Classes. Paris: Didier.

Dalton-Puffer, C. (2007). Discourse in Content-and-Language-Integrated Learning (CLIL) Classrooms. Amsterdam: John Benjamins. http://dx.doi.org/10.1075/11lt.20

Drew, P., \& Heritage, J. (1992). Analyzing Talk at Work: An Introduction. In P. Drew, \& J. Heritage (Eds.), Talk at Work. Interaction in Institutional Settings (pp. 3-65). Cambridge: Cambridge University Press.

Ellis, R. (1984). Classroom Second Language Development. Oxford: Pergamon.

Ellis, R. (2003). Task-Based Language Learning and Teaching. Oxford: Oxford University Press.

Ellis, R. (2012). Language Teaching Research and Language Pedagogy. Malden, MA: John Wiley and Sons. http://dx.doi.org/10.1002/9781118271643

Jenks, C. J. (2007). Floor Management in Task-Based Interaction: The Interactional Role of Participatory Structures. System, 35, 609-622. http://dx.doi.org/10.1016/j.system.2007.06.005

Johnson, K. E. (1995). Understanding Communication in Second Language Classrooms. Cambridge: Cambridge University Press.

Kasper, G. (1985). Repair in Foreign Language Teaching. Studies in Second Language Acquisition, 7, 200-215. http://dx.doi.org/10.1017/S0272263100005374

Labascoule, J., Lause, C., \& Royer, C. (2004). Rond Point 1. Méthode de Français Basée sur l'Apprentissage par les Tâches. Grenoble: Presses Universitaires de Grenoble.

Macaro, E. (2001). Analysing Students Teachers' Codeswitching in Foreign Language Classrooms: Theories and Decision Making. The Modern Language Journal, 85, 531-548. http://dx.doi.org/10.1111/0026-7902.00124

Markee, N., \& Kasper, G. (2004). Classroom Talks: An Introduction. The Modern Language Journal, 88, 491-500. http://dx.doi.org/10.1111/j.0026-7902.2004.t01-14-.x

McHoul, A. (1978). The Organization of Turns at Formal Talk in the Classroom. Language in Society, 7, 183-213. http://dx.doi.org/10.1017/S0047404500005522

Mehan, H. (1985). The Structure of Classroom Discourse. In T. A. van Dijk (Ed.), Handbook of Discourse Analysis, Volume III: Discourse and Dialogue (pp. 119-131). London: Academic Press.

Mori, J. (2002). Task Design, Plan, and Development of Talk-in-Interaction: An Analysis of a Small Group Activity in a Japanese Language Classroom. Applied Linguistics, 23, 323-347. http://dx.doi.org/10.1093/applin/23.3.323

Richards, K. (2005). Introduction. In K. Richards, \& P. Seedhouse (Ed.), Applying Conversation Analysis (pp. 1-15). New York: Palgrave, Macmillan. 
Richards, K., \& Seedhouse, P. (2005). Applying Conversation Analysis. New York: Palgrave, Macmillan.

Samuda, V., \& Bygate, M. (2008). Tasks in Second Language Learning. New York: Palgrave, Macmillan.

Sacks, H., Schegloff, E., \& Jefferson, G. (1974). A Simplest Systematics for the Organization of Turn Taking in Conversation. Language, 50, 696-735. http://dx.doi.org/10.2307/412243

Schegloff, E., Jefferson, G., \& Sacks, H. (1977). The Preference for Self-Correction in the Organization of Repair in Conversation. Language, 53, 361-382.

Schegloff, E. A. (2007). Ch. 1: Introduction to Sequence Organization. In Sequence Organization in Interaction, Volume 1: A Primer in Conversation Analysis (pp. 1-27). Cambridge: Cambridge University Press.

Seedhouse, P. (2004). The Interactional Architecture of the Language Classroom: A Conversation Analysis Perspective. Malden, MA: Blackwell.

Seedhouse, P., \& Almutairi, S. (2009). A Holistic Approach to Task-Based Interaction. International Journal of Applied Linguistics, 19, 311-338. http://dx.doi.org/10.1111/j.1473-4192.2009.00243.x

Sinclair, J., \& Coulthard, R. (1975). Towards an Analysis of Discourse: The English Used by Teachers and Pupils. Oxford: Oxford University Press.

Spada, N., \& Fröhlich, M. (1995). COLT Observation Scheme. Sydney: National Centre for English Language Teaching and Research, Macquarie University.

Springer, C. (2009). La Perspective Actionnelle et l'Approche Par les Tâches en Classe de Langue. Le Français Dans le Monde. Recherches et Applications, 45, 25-34.

Turnbull, M., \& Dailey-O’Cain, J. (2009). First Language Use in Second and Foreign Language Learning. Clevedon: Multilingual Matters.

Ustünel, E., \& Seedhouse, P. (2005). Why that, in that Language, Right Now? Code-Switching and Pedagogical Focus. International Journal of Applied Linguistics, 15, 302-325. http://dx.doi.org/10.1111/j.1473-4192.2005.00093.x

Van Lier, L. (1988). The Classroom and the Language Learner. London: Longman.

Van Lier, L. (1996). Interaction in the Language Curriculum: Awareness, Autonomy and Authenticity. London: Longman.

Wagner, J., \& Gardner, R. (2004). Introduction. In R. Gardner, \& J. Wagner (Eds.), Second Language Conversations (pp. 1-17). New York: Continuum.

Waring, H. Z. (2009). Using Explicit Assessment in the Language Classroom: IRF, Feedback, and Learning Opportunities. The Modern Language Journal, 92, 577-594. http://dx.doi.org/10.1111/j.1540-4781.2008.00788.x

Wong, J., \& Waring, H. Z. (2010). Conversation Analysis and Second Language Pedagogy. A Guide for ES/EL Teachers. New York: Routledge. 


\section{Appendix 1}

\section{Production Task: Master Chef Task Designed by the Teacher}

Dans la boîte mystère il y a des ingrédients et des produits de base. En équipe vous préparez un plat. Utilisez au moins 7 produits. Vous inventez la recette et un nom pour votre plat. Ecrivez la recette de votre plat.

Translation: In the mystery box there are ingredients and basic products. In groups, prepare a dish. Use at least 7 ingredients. You invent the recipe and also you give a name to your dish. Write down your recipe.

\section{La boîte mystère}

Ingrédients

250 grammes d'amandes

$200 \mathrm{ml}$ de rhum brun

1 tablette de chocolat noir

1 tablette de chocolat blanc

200 grammes de gruyère râpé

De l'ail

500 grammes de fraises

Du gingembre

Deux oranges

Deux oignons

Deux poivrons

Quatre tomates

Du piment

500 grammes de calamar

Des lardons

Un poulet entier

Du riz

\section{Produits de base}

500 grammes de beurre

2 kilos de farine

1 litre d'huile d'olive

2 litres de lait

5 sachets de levure

Une douzaine d'oeufs

2 kilos de sucre en poudre

1 litre de vinaigre

Du sel

Du poivre

De la moutarde

\section{Appendix 2}

\section{Transcription Conventions}

Identity of speakers
$\mathrm{T}$ :
teacher
S1:
identified student
S3?:
probably student 3
$\mathrm{S}$ :
unidentified student
Ss:
several students together

Identify errors and language
$*$
an asterisk in front of a word or a syllable indicates an error
$+$ a cross in front of a word or syllable indicates corrected error
L1:
italics
L2:
regular font
Characteristics of speech delivery
? $\quad$ raising intonation
so, a comma indicates low raising intonation suggesting continuation
yes. a period indicates falling intonation
: $\quad$ colons indicate the lengthening of the preceding sound
no- a hyphen indicates an abrupt cut-off
because $\quad$ underlined type indicates stress
put degree signs indicate decreased volume
S. E. R. spelling
$(0.5) \quad(0.5)=$ a pause of 0.5 second
(1.0) $\quad(1.0)=$ a pause of one second
$\mathrm{T}$ : [yes brackets indicate simultaneous overlapping talk by two or more 
S1: oh] speakers

Commentary in the transcript

((laughing)) description of actions such as reading or gesturing.

Non-verbal actions are noted under words when talk and action are simultaneous

'raisins' quotation marks indicate that words are read or extracted from the written document accom-

panying the task

$\mathrm{xx}$

$($ ( $/ / \mathrm{me} / /)$

indicates one or more words that are unintelligible

single parenthesis indicate unclear or probable item

slashes indicate phonetic transcription 